\title{
A cross-sectional study to evaluate diabetes management, control and complications in 1631 patients with type 2 diabetes mellitus in Vietnam (DiabCare Asia)
}

\author{
Khue Thy Nguyen ${ }^{1} \cdot$ Binh Thanh Thi Diep ${ }^{2} \cdot$ Van Dieu Khoa Nguyen ${ }^{3} \cdot$ Hoang Van Lam $^{4} \cdot$ Khanh Quang Tran $^{5}$. \\ Nam Quang Tran ${ }^{2,6}$
}

Received: 22 October 2018 / Accepted: 19 June 2019 / Published online: 21 August 2019

(C) The Author(s) 2019

\begin{abstract}
Aims To assess diabetes care delivery and prevention of short- and long-term diabetes-related complications in patients with type 2 diabetes mellitus (T2DM) in Vietnam.

Methods DiabCare Asia is an observational, non-interventional, cross-sectional study of hospital-based outpatient care for patients diagnosed with T2DM.

Results A total of 1631 patients (mean age 62.7 years; $58.9 \%$ female) participated in the study. The percentage of patients with $\mathrm{HbAlc}<7.0 \%$ (<53 mmol/mol) was 36.1\% and mean (standard deviation) HbAlc was $7.9 \pm 1.8 \%$ (63 $\pm 19 \mathrm{mmol} / \mathrm{mol})$. The proportion of patients using insulin was $40 \%$, at a mean total daily dose of $35.4 \mathrm{U}$. Apart from dyslipidemia (81.2\%) and hypertension (78.4\%), the most common diabetes-related complications were peripheral neuropathy (37.9\%) and eye complications $(39.5 \%)$. Current insulin therapy was associated with peripheral vascular disease (odds ratio [OR] $=2.28[95 \%$ confidence interval (CI) $1.68 ; 3.09])$ and eye complications (OR = 1.70 [95\% CI 1.37; 2.11]).

Conclusion In this sample of patients with T2DM in Vietnam, the majority had poor glycemic and metabolic control. Concerted efforts are needed to optimize control and prevent complications in these patients. Trial registration: NCT02066766
\end{abstract}

Keywords Diabetes mellitus $\cdot$ Hospital care $\cdot$ Prevention $\cdot$ Diabetes complications $\cdot$ Treatment adherence $\cdot$ Hypoglycemia

Electronic supplementary material The online version of this article (https://doi.org/10.1007/s13410-019-00755-w) contains supplementary material, which is available to authorized users.

Khue Thy Nguyen

drthykh@gmail.com

Binh Thanh Thi Diep

diepthithanhbinh54@gmail.com

Van Dieu Khoa Nguyen

dieuvan62@yahoo.com.vn

Hoang Van Lam

lvhcr98@yahoo.com.vn

Khanh Quang Tran

khanh.tran007@yahoo.com

Nam Quang Tran

tranqnam@yahoo.com
1 Hoa Hao Health Center, Ward 4, District 10, Ho Chi Minh City, Vietnam

2 Present address: The Medical University Hospital in Ho Chi Minh City, 215 Hong Bang, District 5, Ho Chi Minh City, Vietnam

3 Bach Mai Hospital, 78 Giai Phong, Phuong Mai, Dong Da, Ha Noi City, Vietnam

4 Cho Ray Hospital, 201B Nguyen Chi Thanh, District 5, Ho Chi Minh City, Vietnam

5 Nguyen Tri Phuong Hospital, 468 Nguyen Trai, District 5, Ho Chi Minh City, Vietnam

6115 Hospital, 527 Su Van Hanh, District 5, Ho Chi Minh City, Vietnam 


\section{Introduction}

In 2017, there were 425 million people diagnosed with diabetes worldwide. The Southeast Asia region is home to approximately 82 million people living with diabetes, and there are approximately 159 million people living with diabetes in the Western Pacific region. The prevalence of diabetes in both regions already exceeds that of Europe, South and Central America, and Africa, and, by 2045, the prevalence in the Western Pacific region is expected to reach 183 million [1]. Furthermore, undiagnosed diabetes represents a significant health problem [2], leading to an increase in the burden of disease, which includes diabetesrelated complications. Therefore, diabetes presents significant challenges to developing countries in the above regions [2-5]. Between 1990 and 2010, the total disability-adjusted life years (DALYs), a measure of overall disease burden, attributable to diabetes increased by nearly $70 \%$, while DALYs attributed to cardiovascular disease (CVD) and cancer each increased by approximately $25 \%$ in the Asia-Pacific region [5].

In Vietnam, the prevalence of diabetes has almost doubled within the past 10 years and has consequently been recognized as a major public health burden. In 2012, the prevalence of diabetes was $5.4 \%$, with an additional $13.7 \%$ of individuals exhibiting impaired glucose tolerance. Recent studies have reported a diabetes prevalence of $7.2 \%$ in central Vietnam [6-8]. Factors contributing to this increase in prevalence of diabetes in Vietnam include a change in the economic landscape toward a more industrial-based economy, urbanization, a change in dietary habits (i.e., an increase in meat and fat intake), aging of the population, increased tobacco smoking, and an increased prevalence of hypertension [6, 9-11].

Severe micro- and macrovascular complications are common in patients with diabetes, particularly in those with poor glycemic control $[12,13]$. There were 480,000 diabetesrelated deaths associated with the above complications in people $<60$ years of age in the Western Pacific region in 2017 [1]. Treatment costs for diabetes-related complications can be significant, with a recent Vietnamese study reporting that type 2 diabetes mellitus (T2DM) therapy costs 246.10 USD annually per patient [14] - an appreciable cost within the context of the 150 USD average Vietnamese monthly salary.

The series of cross-sectional, observational DiabCare studies aimed to assess diabetes management, control, and diabetes-related complications in patients with T2DM [15-23]. The studies also evaluated both primary and secondary preventative efforts, and patients' treatment adherence to inform healthcare policy and modify diabetes management programs [15-23]. In 1998, DiabCare Asia conducted the first regional survey that included Vietnam $[15,16]$. Since this survey, only local and smaller studies have been conducted. Thus, there is a need for national data to inform the treatment and prevention of T2DM and to help raise awareness of diabetes among Vietnamese healthcare professionals (HCPs), as well as to plan educational programs and the provision of medical insurance. The current DiabCare Asia study aims to report on diabetes management, glycemic and metabolic control, and prevalence of diabetes-related complications in patients with T2DM in Vietnam.

\section{Methods}

\section{Study design}

DiabCare Asia was an observational, non-interventional, cross-sectional study conducted in Bangladesh, Indonesia, Malaysia, Philippines, Sri Lanka, and Vietnam (Clinicaltrials.gov registration number: NCT02066766). The current manuscript reports data from the Vietnam cohort only, involving diabetes clinics/units of 43 districts, provincial, and central hospitals in Vietnam between April 2015 and August 2015. Due to the observational nature of this study, there were no study-specific visits or investigational products and patients were treated according to routine clinical practice at the discretion of their physician.

\section{Study participants}

Patients routinely visiting the centers during the study period were screened for eligibility. Adults $>18$ years with T2DM receiving non-pharmacological or pharmacological treatment at a particular center for $\geq 1$ year and who had visited the center within the last 3-6 months were included. Patients who had suspected or confirmed pregnancy, or who were unable to comply with protocol requirements (any procedure related to recording of data, including patient interview and completion of questionnaires), were excluded from the study. Patients could withdraw from the study at any time. All patients meeting the inclusion criteria during the recruitment period were enrolled in the study.

\section{Study endpoints}

The primary endpoint of the study was the proportion of patients with glycosylated hemoglobin $(\mathrm{HbA} 1 \mathrm{c})<7.0 \%$ $(<53 \mathrm{mmol} / \mathrm{mol})$. Secondary endpoints included duration of diabetes, duration and type of antidiabetic treatment, measures of glycemic control and lipid control, and presence of known risk factors or diabetes-related complications. Potential risk factors were analyzed for their relationship with diabetesrelated complications. Full details of secondary endpoints and potential risk factors are detailed in Supplementary Methods. 


\section{Assessments}

Relevant data were collected by patient interview and from patients' medical records and recorded in studyspecific case report forms. Data collected from the medical records included demography, medical history, diabetes-related complications, eye and foot examinations, diabetes management, and most recent laboratory investigations performed in the previous year. Blood samples obtained from all patients at study entry were assessed centrally for $\mathrm{HbA} 1 \mathrm{c}$. Patients completed a treatment adherence questionnaire, a hypoglycemia questionnaire, and the EQ-5D health-related quality of life questionnaire [24], as detailed in Supplementary Methods.

Patient data were kept confidential and stored according to local data protection regulations.

\section{Sample size}

The prevalence estimates and sample size were estimated based on published data [25]; local external experts advised on the list of clinics visited by most patients for diabetes care, to ensure a representative national sample to fulfill the objectives of the study.

Prevalence of CVD was used as a basis for the sample size target as available literature suggests that this is the least prevalent of all diabetes-related complications and its use confers the maximum possible representativeness to the sample size estimate. Assuming a CVD prevalence of $1 \%$, a sample of 2000 patients from Vietnam was required to attain a $5 \%$ level of significance and a $30 \%$ margin of error.

\section{Statistical analysis}

The full analysis set included all patients enrolled in the study with at least one data point, and was used for all analyses. Missing data were not replaced. Continuous variables were summarized using descriptive statistics ( $n$, mean, SD). Categorical variables were presented as number and percentages of patients (\%). The number of missing observations is displayed and percentages are calculated based on the total number of patients in each category. For diabetes-related complications, patients with missing values were assumed not to have the complication in question.

The association between potential risk factors and diabetes-related complications was analyzed as detailed in Supplementary Methods.

\section{Results}

\section{Patient characteristics}

In total, 1631 patients participated in the study. Mean patient age was 62.7 years and the majority of patients $(58.9 \%)$ were female. Mean duration of diabetes was 9.5 years. A large proportion of patients $(39.4 \%$ ) had a family history of diabetes, $49.2 \%$ of patients led a sedentary lifestyle, and $14.1 \%$ were current smokers (Table 1).

\section{Diabetes management}

The majority of patients $(86.3 \%)$ were receiving oral or non-insulin injectable therapies, and $40.0 \%$ were on insulin treatment at a mean total daily dose of $35.4 \mathrm{U}$ (Table 2).

Table 1 Patient characteristics

\begin{tabular}{|c|c|}
\hline Variable & \\
\hline \multicolumn{2}{|l|}{ Age (years) } \\
\hline$N$ & 1631 \\
\hline Mean (SD) & $62.7(10.4)$ \\
\hline \multicolumn{2}{|l|}{ Gender, $N(\%)$} \\
\hline Male & $671(41.1)$ \\
\hline Female & $960(58.9)$ \\
\hline \multicolumn{2}{|l|}{ Race, $N(\%)$} \\
\hline Vietnamese & $1626(99.7)$ \\
\hline Danish & $2(0.1)$ \\
\hline German & $1(0.1)$ \\
\hline Missing & $2(0.1)$ \\
\hline \multicolumn{2}{|c|}{ Body weight $(\mathrm{kg})$} \\
\hline$N$ & 1620 \\
\hline Mean (SD) & $59.7(10.4)$ \\
\hline \multicolumn{2}{|l|}{ BMI $\left(\mathrm{kg} / \mathrm{m}^{2}\right)$} \\
\hline$N$ & 1609 \\
\hline Mean (SD) & $23.9(3.5)$ \\
\hline \multicolumn{2}{|c|}{ Duration of diabetes (years) } \\
\hline$N$ & 1630 \\
\hline Mean (SD) & $9.5(6.5)$ \\
\hline \multicolumn{2}{|c|}{ Duration of treatment (years) } \\
\hline$N$ & 1630 \\
\hline Mean (SD) & $9.3(6.4)$ \\
\hline \multicolumn{2}{|c|}{ Duration of OAD treatment (years) } \\
\hline$N$ & 1589 \\
\hline Mean (SD) & $8.6(6.0)$ \\
\hline \multicolumn{2}{|c|}{ Duration of insulin treatment (years) } \\
\hline$N$ & 674 \\
\hline Mean (SD) & $3.8(3.9)$ \\
\hline
\end{tabular}

Demographic parameters and clinical and treatment history data were collected from medical records

$B M I$, body mass index; $O A D$, oral antidiabetic drug; $S D$, standard deviation 
Table 2 Antidiabetic therapies

Variable

Receiving current oral or non-insulin injectable therapy

$N(\%)$

Missing

$407(86.3)$

Antidiabetic therapy, $N(\%)$

Metformin

Sulfonylurea

Glucosidase inhibitor

Thiazolidinedione

Herbal

Glinide

DPP-4 inhibitor

GLP-1RA

Missing

Receiving current insulin therapy

$N(\%)$

Missing

Insulin injection type, $N(\%)$

Pen

Vial/syringe

Missing

Insulin regimen, $N(\%)$

Basal + OAD

Basal-bolus

Premix BID

Premix OD

Premix TID

Other

Missing

Number of daily injections

$N$

Missing

Mean (SD)

Total daily insulin dose (U)

$\begin{array}{ll}N & 638 \\ \text { Missing } & 15 \\ \text { Mean (SD) } & 35.4(18.1)\end{array}$

Treatment history data were collected from medical records

$B I D$, twice daily; $D P P-4$, dipeptidyl peptidase-4; GLP-1RA, glucagonlike peptide-1 receptor agonist; $O A D$, oral antidiabetic drug; $O D$, once daily; TID, three times daily

The most commonly used oral antidiabetic drug (OAD) was metformin $(86.2 \%)$ and the most commonly prescribed insulin regimen was premix twice-daily (BID) (63.7\%). Most patients had been evaluated for HbA1c $(91.9 \%)$ in the previous year (Table 3 ), with a mean of 2.8 tests per year.

\section{Treatment adherence}

A large proportion of patients only partially adhered to clinical recommendations regarding diet $(47.8 \%)$ and
Table 3 Glycemic and metabolic parameters

Variable

$\mathrm{HbAlc}$

$N=1622$

Mean (SD), \% $7.9(1.8)$

Mean (SD), $\mathrm{mmol} / \mathrm{mol} \quad 63$ (19)

HbAlc categories, $N(\%)$

$<7.0 \%(<53 \mathrm{mmol} / \mathrm{mol}) \quad 589(36.1)$

$7.0<8.0 \%(53-<64 \mathrm{mmol} / \mathrm{mol}) \quad 397(24.3)$

$8.0<9.0 \%(64<75 \mathrm{mmol} / \mathrm{mol}) \quad 282(17.3)$

$9.0<10.0 \%(75-86 \mathrm{mmol} / \mathrm{mol}) \quad 158(9.7)$

$\geq 10.0 \%(\geq 86 \mathrm{mmol} / \mathrm{mol}) \quad 196(12.0)$

Missing

$\mathrm{HbA} 1 \mathrm{c}$ tested in last year

$N(\%)$

Missing

$9(0.6)$

Number of $\mathrm{HbAlc}$ tests in previous year $N$

$1499(91.9)$

$7(0.4)$

Mean (SD)

1437

$2.8(1.2)$

SMBG tested in last year

$N(\%)$

Missing

773 (47.4)

$2(0.1)$

Number of SMBG tests in previous year

$N$

Mean (SD)

764

FPG $(\mathrm{mmol} / \mathrm{l})$

$N$

$6.2(8.6)$

Mean (SD)

PPG (mmol/l)

$N$

Mean (SD)

Systolic blood pressure ( $\mathrm{mmHg}$ )

$N$

Mean (SD)

$8.0(2.7)$

492

$11.6(4.0)$

1618

$129.1(15.9)$

Diastolic blood pressure (mmHg)

1618

Mean (SD)

Total cholesterol (mmol/l)

N

Mean (SD)

$76.6(8.6)$

HDL cholesterol (mmol/l)

N

Mean (SD)

LDL cholesterol (mmol/l)

$N$

Mean (SD)

1436

$7.6(27.4)$

1394

$1.9(6.8)$

1377

Triglycerides $(\mathrm{mmol} / \mathrm{l})$

$N$

$5.0(20.6)$

Mean (SD)

1443

$5.4(12.7)$

Blood samples were obtained from all patients at study entry for $\mathrm{HbAlc}$ assessment by a central laboratory. Clinical history and data from most recent laboratory investigations within the past year were collected from medical records

$F P G$, fasting plasma glucose; $H D L$, high-density lipoprotein; $L D L$, lowdensity lipoprotein; $P P G$, postprandial plasma glucose; $S D$, standard deviation; $S M B G$, self-measured blood glucose

exercise (37.8\%; Supplementary Table 1). Many patients never self-tested $(40.6 \%), 9.0 \%$ of patients did not fully adhere to their prescribed medications, and $10.7 \%$ did not completely adhere to scheduled appointments with HCPs. 


\section{Glycemic and metabolic endpoints}

Mean $\mathrm{HbAlc}$ was $7.9 \% \pm 1.8 \%(63 \pm 19 \mathrm{mmol} / \mathrm{mol}$; Table 3$)$. $\mathrm{HbAlc}$ target of $<7.0 \%(<53 \mathrm{mmol} / \mathrm{mol})$, as recommended by the American Diabetes Association (ADA) [25], was met by $36.1 \%$ of patients, with $51.3 \%$ of patients having $\mathrm{HbAlc}$ of $7.0<10.0 \%(53-86 \mathrm{mmol} / \mathrm{mol})$ and $12.0 \%$ of patients having $\mathrm{HbAlc} \geq 10.0 \%(\geq 86 \mathrm{mmol} / \mathrm{mol})$.

A high proportion of patients $(78.4 \%)$ had hypertension (defined as [i] currently taking medication for hypertension, or [ii] systolic blood pressure $\geq 140 \mathrm{mmHg}$ or diastolic blood pressure $\geq 90 \mathrm{mmHg}$ ), and $74.9 \%$ were receiving antihypertensive medication. There was also a high proportion of patients $(81.2 \%)$ with dyslipidemia (defined as [i] lowdensity lipoprotein [LDL] cholesterol $>2.6 \mathrm{mmol} / \mathrm{l}$, or [ii] high-density lipoprotein [HDL] cholesterol $<1.0 \mathrm{mmol} / 1$ in males and $<1.3 \mathrm{mmol} / \mathrm{l}$ in females, or [iii] triglycerides $>1.7 \mathrm{mmol} / \mathrm{l}$ or currently taking medication for dyslipidemia), and $69.8 \%$ were on dyslipidemia medication.

\section{Diabetes-related complications and management}

Aside from hypertension and dyslipidemia, the most prevalent complications were peripheral neuropathy (37.9\%) and eye complications (39.5\%; Table 4). One-third of patients (33.4\%) had cardiovascular complications, of which angina was the most frequently reported (19.9\%), and almost a quarter of patients had renal complications $(24.1 \%)$.

Anti-hypertensive treatment (angiotensin-converting-enzyme inhibitors and/or angiotensin-receptor blockers) was the most common intervention for primary and secondary prevention of complications (47.8\% and $46.8 \%$, respectively), followed by lipid-lowering treatment (statins; $47.1 \%$ and 40.3\%, respectively), and anti-platelet treatment (aspirin; $22.8 \%$ and $22.7 \%$, respectively). A small proportion of patients were on primary and secondary foot ulcer prevention programs (9.3\% and 5.7\%, respectively), or foot ulcer special care treatment (8.9\%). Over the previous 2 years, $62.0 \%$ and $46.4 \%$ of patients had been screened for eye complications and peripheral neuropathy, respectively.

In the multivariate analysis assessing potential risk factors for diabetes complications, dyslipidemia was independently associated with age (adjusted OR, 1.01), male gender (OR, 1.33), and fasting plasma glucose (FPG) (OR, 0.95; Table 5). Hypertension was independently associated with use of multiple OADs (OR, 0.71), insulin therapy (OR, $0.37)$, body mass index (BMI) (OR, 0.85), and age (OR, 0.92).

Diabetes duration was associated with peripheral vascular disease (OR, 1.03), diabetic nephropathy (OR, 1.05) and eye complications (OR, 1.06). Current treatment with insulin, and hypertension were both independently associated with higher odds of cardiovascular complications (OR, 1.46 and 2.88, respectively), peripheral vascular disease (OR, 2.28 and
Table 4 Proportion of patients with diabetes-related complications

\begin{tabular}{|c|c|}
\hline Complication, $N(\%)$ & $\begin{array}{l}\text { All subjects } \\
(N=1631)\end{array}$ \\
\hline $\begin{array}{l}\text { Dyslipidemia }^{\mathrm{a}} \\
\text { Missing }\end{array}$ & $\begin{array}{l}1324(81.2) \\
1(0.1)\end{array}$ \\
\hline $\begin{array}{l}\text { Hypertension } \\
\text { Missing }\end{array}$ & $\begin{array}{l}1278(78.4) \\
0(0.0)\end{array}$ \\
\hline $\begin{array}{l}\text { Any recorded eye complications } \\
\text { Missing }\end{array}$ & $\begin{array}{l}644(39.5) \\
10(0.6)\end{array}$ \\
\hline $\begin{array}{l}\text { Cataract } \\
\text { Missing }\end{array}$ & $\begin{array}{l}467(28.6) \\
11(0.7)\end{array}$ \\
\hline $\begin{array}{l}\text { Non-proliferative diabetic retinopathy } \\
\text { Missing }\end{array}$ & $\begin{array}{l}213(13.1) \\
16(1.0)\end{array}$ \\
\hline $\begin{array}{l}\text { Diabetic retinopathy } \\
\text { Missing }\end{array}$ & $\begin{array}{l}189(11.6) \\
15(0.9)\end{array}$ \\
\hline $\begin{array}{l}\text { Proliferative diabetic retinopathy } \\
\text { Missing }\end{array}$ & $\begin{array}{l}73(4.5) \\
16(0.1)\end{array}$ \\
\hline $\begin{array}{l}\text { Severe vision loss } \\
\text { Missing }\end{array}$ & $\begin{array}{l}52(3.2) \\
10(0.6)\end{array}$ \\
\hline $\begin{array}{l}\text { Macular edema } \\
\text { Missing }\end{array}$ & $\begin{array}{l}42(2.6) \\
16(0.1)\end{array}$ \\
\hline $\begin{array}{l}\text { Peripheral neuropathy } \\
\text { Missing }\end{array}$ & $\begin{array}{l}618(37.9) \\
4(0.2)\end{array}$ \\
\hline $\begin{array}{l}\text { Erectile dysfunction }{ }^{\mathrm{c}} \\
\text { Missing }\end{array}$ & $\begin{array}{l}223(33.2) \\
2(0.3)\end{array}$ \\
\hline $\begin{array}{l}\text { Any recorded cardiovascular complications } \\
\text { Missing }\end{array}$ & $\begin{array}{l}544(33.4) \\
1(0.1)\end{array}$ \\
\hline $\begin{array}{l}\text { Angina } \\
\text { Missing }\end{array}$ & $\begin{array}{l}324(19.9) \\
2(0.1)\end{array}$ \\
\hline $\begin{array}{l}\text { Peripheral vascular disease } \\
\text { Missing }\end{array}$ & $\begin{array}{l}188(11.5) \\
1(0.1)\end{array}$ \\
\hline $\begin{array}{l}\text { Left ventricular hypertrophy } \\
\text { Missing }\end{array}$ & $\begin{array}{l}158(9.7) \\
1(0.1)\end{array}$ \\
\hline $\begin{array}{l}\text { Stroke } \\
\text { Missing }\end{array}$ & $\begin{array}{l}71(4.4) \\
1(0.1)\end{array}$ \\
\hline $\begin{array}{l}\text { Myocardial infarction } \\
\text { Missing }\end{array}$ & $\begin{array}{l}45(2.8) \\
1(0.1)\end{array}$ \\
\hline $\begin{array}{l}\text { Congestive heart failure } \\
\text { Missing }\end{array}$ & $\begin{array}{l}15(0.9) \\
2(0.1)\end{array}$ \\
\hline $\begin{array}{l}\text { Atrial fibrillation } \\
\text { Missing }\end{array}$ & $\begin{array}{l}10(0.6) \\
1(0.1)\end{array}$ \\
\hline $\begin{array}{l}\text { Any recorded renal complication } \\
\text { Missing }\end{array}$ & $\begin{array}{l}393(24.1) \\
3(0.2)\end{array}$ \\
\hline $\begin{array}{l}\text { Microalbuminuria } \\
\text { Missing }\end{array}$ & $\begin{array}{l}343(21.0) \\
67(4.1)\end{array}$ \\
\hline $\begin{array}{l}\text { Gross proteinuria } \\
\text { Missing }\end{array}$ & $\begin{array}{l}183(11.2) \\
55(3.4)\end{array}$ \\
\hline $\begin{array}{l}\text { End-stage renal disease } \\
\text { Missing }\end{array}$ & $\begin{array}{l}26(1.6) \\
3(0.2)\end{array}$ \\
\hline $\begin{array}{l}\text { Dialysis } \\
\text { Missing }\end{array}$ & $\begin{array}{l}5(0.3) \\
3(0.2)\end{array}$ \\
\hline $\begin{array}{l}\text { Any recorded foot complications } \\
\text { Missing }\end{array}$ & $\begin{array}{l}103(6.3) \\
1(0.1)\end{array}$ \\
\hline $\begin{array}{l}\text { Healed ulcer } \\
\text { Missing }\end{array}$ & $\begin{array}{l}82(5.0) \\
2(0.1)\end{array}$ \\
\hline $\begin{array}{l}\text { Ulcer infection } \\
\text { Missing }\end{array}$ & $\begin{array}{l}51(3.1) \\
1(0.1)\end{array}$ \\
\hline
\end{tabular}


Table 4 (continued)

\begin{tabular}{cl}
\hline Complication, $N(\%)$ & $\begin{array}{l}\text { All subjects } \\
(N=1631)\end{array}$ \\
\hline Active ulcer & $22(1.3)$ \\
Missing & $1(0.1)$ \\
History of amputation & $14(0.9)$ \\
Missing & $1(0.1)$
\end{tabular}

${ }^{a}$ Dyslipidemia: (i) LDL cholesterol $>2.6 \mathrm{mmol} / \mathrm{l}$ or (ii) $\mathrm{HDL}$ cholesterol $<1.0 \mathrm{mmol} / 1$ in males and $<1.3 \mathrm{mmol} / 1$ in females, or (iii) TG $>1.7 \mathrm{mmol} / 1$ or currently taking medication for dyslipidemia

${ }^{\mathrm{b}}$ Hypertension: (i) currently taking medication for hypertension, or (ii) systolic blood pressure $\geq 140 \mathrm{mmHg}$, or diastolic blood pressure $\geq 90 \mathrm{mmHg}$

${ }^{\mathrm{c}}$ Based on the total number of male patients $(n=671)$. Diabetes-related complication data were collected from medical records. Patients with missing observations were assumed not to have the complication in question

$H D L$, high-density lipoprotein; $L D L$, low-density lipoprotein; $T G$, triglycerides

1.93, respectively), diabetic nephropathy (OR, 1.94 and 1.67, respectively), and eye complications (OR, 1.70 and 1.27, respectively). HbA1c was associated with cardiovascular complications (OR, 1.07), peripheral vascular disease (OR, 1.09), and eye complications (OR, 1.06).

\section{Hypoglycemic episodes}

Symptoms of mild, moderate, severe, and nocturnal hypoglycemia within the previous 3 months were reported by $39.7 \%$, $2.8 \%, 1.3 \%$, and $8.2 \%$ of patients, respectively (Supplementary Table 2). Among patients who had experienced hypoglycemia, most (88.6\%) did not check their blood glucose or only checked it occasionally, and only $10.6 \%$ of patients always measured their blood glucose when a hypoglycemic event occurred. Most patients (97.1\%) who had experienced hypoglycemia did not visit or only occasionally visited a hospital during an event. Following a hypoglycemic episode, $88.8 \%$ snacked between meals and $8.2 \%$ of patients skipped or reduced their diabetes medications. Most patients $(59.8 \%)$ indicated that they were not worried about hypoglycemia.

\section{EQ-5D VAS and health status questionnaire}

Patients reported a healthy state of overall well-being on the EQ-5D visual analogue scale (VAS), with a mean $( \pm \mathrm{SD})$ score of $71.3 \pm 16.9$ (on a scale of $0-100$ ). However, in the EQ-5D health status questionnaire, many patients reported moderate pain or discomfort (32.6\%), and moderate anxiety or depression (26.8\%; Supplementary Table 3).

\section{Discussion}

This study provides an overview of the status of diabetes care in patients with T2DM treated in various hospital care settings in Vietnam in 2015. With regard to the primary endpoint, $36.1 \%$ of patients had $\mathrm{HbAlc}<7.0 \%(<53 \mathrm{mmol} / \mathrm{mol})$ and the mean HbAlc was $7.9 \%$ (63 mmol $/ \mathrm{mol})$. This study was similar in design to the DiabCare Asia 1998 study, which also recruited all eligible patients with T2DM treated at hospital or referral clinics in Vietnam. The DiabCare Asia 1998 study group reported that $18 \%$ of patients in Vietnam had HbAlc $<7.0 \%$ $(<53 \mathrm{mmol} / \mathrm{mol})$ and a mean $\mathrm{HbAlc}$ of $8.9 \%(74 \mathrm{mmol} / \mathrm{mol})$ [15]. Thus, the current data indicate that glycemic control has improved from 1998 to the present day and suggest an improvement in the standard of care for patients with T2DM in Vietnam.

While these data indicate that the proportion of patients with T2DM in Vietnam achieving recommended glycemic targets has increased over time, the majority of the cohort (i.e., around $63 \%$ ) had $\mathrm{HbAlc}>7.0 \%$ (>53 $\mathrm{mmol} / \mathrm{mol}$ ), with a notable minority $(12 \%)$ of patients presenting with $\mathrm{HbAlc} \geq 10.0 \%$ ( $\geq 86 \mathrm{mmol} / \mathrm{mol}$ ). Several possible reasons may underlie this suboptimal glycemic control. Firstly, the frequency of testing was lower than that recommended by the ADA [26], with many patients not monitoring their blood glucose levels at all in the past year. This lack of testing may be attributable to public health factors such as no local provision for testing and a lack of health insurance cover; health insurance was only introduced in Vietnam in the last two decades and is still not universal [27]. Secondly, a high proportion of patients did not adhere to treatment-related advice and a substantial proportion did not adhere to their prescribed treatment regimens. Thirdly, about half of the patient cohort led a sedentary lifestyle with no exercise. Finally, the prevalence of diabetes in Vietnam is increasing due to an aging population, and changes in lifestyle and dietary patterns, resulting in a significant public health burden [6].

The Vietnamese government has unveiled a national strategy for non-communicable diseases for 2015-2025 that explicitly includes the control and prevention of diabetes. In order for this goal to be achieved, the current data indicate that more work is required within diabetes treatment services in Vietnam. In particular, these findings emphasize the need to promote frequent $\mathrm{HbAlc}$ testing and improve patient adherence to lifestyle modification and medication. To improve the quality of care, the ADA advocates that diabetes services should follow the chronic care model [27]. Moreover, recruitment of specialist staff such as nutritionists and diabetes specialist nurses may be needed in Vietnam. Educational programs delivered by diabetes educators would also likely improve outcomes in Vietnamese patients diagnosed with T2DM.

Patients with T2DM are predisposed to developing hypertension and dyslipidemia, which are known to increase the risk of late complications such as end-stage renal failure and cardiovascular events [28-31]. In this study, the high proportion of patients 


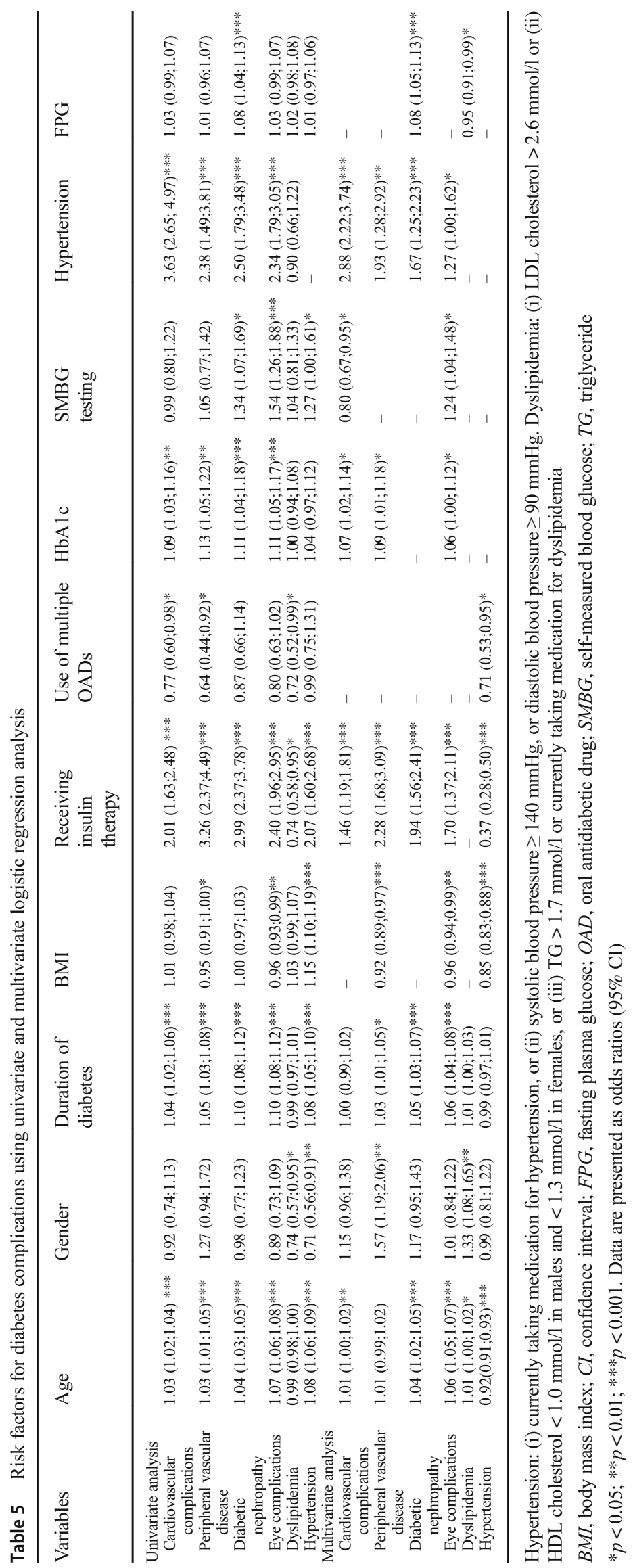


with dyslipidemia (81.2\%) and hypertension (78.4\%) irrespective of treatment for these conditions is a cause for concern. Indeed, the prevalence of hypertension was higher in the current study (78.4\%) than reported in DiabCare Asia 1998 (61.0\%) [15]. Interestingly, it was found that treatment with multiple OADs, current use of insulin therapy, BMI, and age were associated with hypertension in the patient cohort. This corroborates previous research indicating that older age and OAD use is associated with poor blood pressure control in patients with diabetes [32]. The relationship between insulin and hypertension may require further analysis, as insulin use can indicate late-phase diabetes in which hypertension may be more common compared with earlier stages in the disease pathway [33]. Age, male gender, and FPG were significantly associated with dyslipidemia. The lack of a significant association between $\mathrm{HbAlc}$ and dyslipidemia was perhaps surprising based on previous research [34-36].

Diabetes-related complications were prevalent, with the most common (excluding hypertension and dyslipidemia) being eye complications and peripheral neuropathy - both of which, encouragingly, were screened for in a relatively high proportion of patients (e.g., $62.0 \%$ of patients had been screened for eye complications). The previous DiabCare Asia 1998 study reported the most common complications in patients with T2DM were cataract, neuropathy, and retinopathy [15]. Neuropathy was only slightly more common in the current study compared with DiabCare Asia 1998, occurring in $37.9 \%$ and $35.0 \%$ of patients, respectively [15]. Eye complications were significantly associated with the most common risk factors observed in the current study (age, diabetes duration, BMI, current insulin therapy, HbAlc, and hypertension). Microalbuminuria occurred in $21 \%$ of patients in the current study compared with $45 \%$ of patients in DiabCare Asia 1998. This finding could be explained by the increased use of medications that reduce albuminuria, such as inhibitors of the renin-angiotensin-aldosterone system. These findings emphasize the importance of early identification of patients at risk of developing diabetes-related complications and implementing more effective preventative efforts - primarily targeted at improving overall glycemic and metabolic control-in Vietnam [12, 13, 37].

It is now well recognized that hypoglycemia can have deleterious physical and psychological consequences that can significantly impact the functioning of patients with diabetes [38, 39]. In the current study, patient responses to the hypoglycemia questionnaire showed that the majority did not check or only occasionally checked their blood glucose during a hypoglycemic event. Furthermore, around one-third of patients skipped or reduced their diabetes medications following an episode. These findings call for strategies to increase patients' awareness of the benefits of diabetes treatment, and for the development of measures to avoid and/or mitigate the impact of hypoglycemia in patients with T2DM in Vietnam.
There are several limitations to the current study. Due to the cross-sectional, observational design of the study, it was not possible to draw conclusions on the cause-and-effect relationship between risk factors and dyslipidemia, hypertension, and various diabetes-related complications. As all centers offered specialized diabetes care services, patients attending these centers who were eligible for study enrollment may not be representative of the Vietnamese T2DM patient population. The relatively high prevalence of CVD may reflect that patients attending these centers had more advanced disease than the general Vietnamese T2DM population. Treatment adherence, hypoglycemia, and EQ5D were self-reported and, consequently, the estimates may have been subject to recall and/or desirability bias. Also, due to the retrospective collection of laboratory findings (aside from $\mathrm{HbAlc}$ ), it was not possible to fully assess the glycemic control and lipid control status in the entire study cohort. Some important aspects of diabetes management, including patient literacy, were also not assessed, and it would have been interesting to ascertain the number of HCPs adhering to national guidelines on diabetes care. Lastly, the patient sample size was smaller than planned due to administration delays and financial constraints; nevertheless, the relatively large number of patients allow for valid observations to be drawn.

\section{Conclusion}

While glycemic control in patients with T2DM has improved in Vietnam from 1998 to the present day, most patients still have unsatisfactory glycemic and metabolic control, with a high prevalence of diabetes-related complications and suboptimal treatment adherence. Improvements in diabetes services are likely needed to better these outcomes. Finally, future studies are needed to continue to monitor diabetes care in Vietnam and to direct and improve diabetes management.

Acknowledgment The authors thank the teams of trial investigators and sub-investigators, the Novo Nordisk trial team, and the patients who participated in the trial. See Supplementary Table 4 for a list of participating sites and responsible investigators.

Data accessibility The subject level analysis data sets for the research presented in the publication are available from the corresponding author on reasonable request.

Author contributions KTN revised the protocol before disseminating it to the sites and followed up all the data collecting process of the study in all sites before the analysis. All authors contributed to subject recruitment, data collection, review and discussion of the trial report, and review and discussion of the manuscript.

Funding information The study was funded by Novo Nordisk A/S, Denmark. Medical writing and editorial assistance was provided by Liam Gillies PhD, Helen Parker PhD, and Erin Slobodian of Watermeadow Medical, an Ashfield company, part of UDG Healthcare PLC, funded by Novo Nordisk. 


\section{Compliance with ethical standards}

Ethical approval The study was conducted in accordance with the Declaration of Helsinki [40] and the Guidelines for Good Pharmacoepidemiology Practice (GPP) [41].

Informed consent Before any study-related activity, eligible patients were provided with oral and written study information, and their informed consent was obtained.

Conflict of interest Dr. KTN has received honoraria for lectures and meeting chairs from Abbott, Astra Zeneca, Aventis, Boehringer Ingelheim, MSD, Novo Nordisk, Sanofi, and Servier. Dr. BTTD, Dr. VKDN, Dr. HVL, Dr. KQT and Dr. NQT have nothing to disclose.

Open Access This article is distributed under the terms of the Creative Commons Attribution 4.0 International License (http:// creativecommons.org/licenses/by/4.0/), which permits unrestricted use, distribution, and reproduction in any medium, provided you give appropriate credit to the original author(s) and the source, provide a link to the Creative Commons license, and indicate if changes were made.

\section{References}

1. IDF Diabetes Atlas. 8th ed: International Diabetes Federation, http://www.diabetesatlas.org/resources/2017-atlas.html; 2017 Accessed 1 Oct 2018.

2. World Health Organization. Noncommunicable diseases in the South-East Asia Region: 2011 situation and response, http://www. searo.who.int/nepal/mediacentre/2011_non_communicable diseases_in_the_south_east_asia_region.pdf 2011 Accessed 1 Oct 2018 .

3. World Health Organization. Action plan for the prevention and control of noncommunicable diseases in South-East Asia, 20132020, http://www.searo.who.int/entity/noncommunicable diseases/documents/sea_ncd_89/en/; 2013 Accessed 1 Oct 2018.

4. Chan JC, Malik V, Jia W, Kadowaki T, Yajnik CS, Yoon KH, et al. Diabetes in Asia: epidemiology, risk factors, and pathophysiology. JAMA. 2009;301:2129-40.

5. Low WY, Lee YK, Samy AL. Non-communicable diseases in the Asia-Pacific region: prevalence, risk factors and community-based prevention. Int J Occup Med Environ Health. 2015;28:20-6.

6. Nguyen TK. Diabetes in Vietnam. Ann Glob Health. 2015;81:870-3.

7. National Hospital of Endocrinology (2012) National program on diabetes control and prevention [in Vietnamese]. 2nd ed. Hanoi: Medical Publisher

8. Miyakawa M, Shimizu T, Van Dat N, Thanh P, Thuy PT, Anh NT, et al. Prevalence, perception and factors associated with diabetes mellitus among the adult population in central Vietnam: a population-based, cross-sectional seroepidemiological survey. BMC Public Health. 2017;17:298

9. Son PT, Quang NN, Viet NL, Khai PG, Wall S, Weinehall L, et al. Prevalence, awareness, treatment and control of hypertension in Vietnam - results from a national survey. J Hum Hypertens. 2012;26:268-80.

10. World Health Organization. Global Adult Tobacco Survey (GATS): Viet Nam 2010, https://www.who.int/tobacco/surveillance/en_tfi_ gats_vietnam report.pdf; 2010 Accessed 1 Oct 2018.

11. Khan NC, Khoi HH. Double burden of malnutrition: the Vietnamese perspective. Asia Pac J Clin Nutr. 2008;17(Suppl 1):116-8.

12. Stratton IM, Adler AI, Neil HA, Matthews DR, Manley SE, Cull $\mathrm{CA}$, et al. Association of glycaemia with macrovascular and microvascular complications of type 2 diabetes (UKPDS 35): prospective observational study. BMJ. 2000;321:405-12.

13. Holman RR, Paul SK, Bethel MA, Matthews DR, Neil HA. 10-year follow-up of intensive glucose control in type 2 diabetes. N Engl $\mathrm{J}$ Med. 2008;359:1577-89.

14. Le NTD, Dinh Pham L, Quang Vo T. Type 2 diabetes in Vietnam: a cross-sectional, prevalence-based cost-of-illness study. Diabetes Metab Syndr Obes. 2017;10:363-74.

15. Nitiyanant W, Tandhanand S, Mahtab H, Zhu XX, Pan CY, Raheja BS, et al. The Diabcare-Asia 1998 study_outcomes on control and complications in type 1 and type 2 diabetic patients. Curr Med Res Opin. 2002;18:317-27.

16. Chuang LM, Tsai ST, Huang BY, Tai TY, Diabcare-Asia 1998 Study Group. The status of diabetes control in Asia-a crosssectional survey of 24317 patients with diabetes mellitus in 1998 . Diabet Med. 2002;19:978-85.

17. Mafauzy M. An audit on diabetes management in Asian patients treated by specialists: the Diabcare-Asia 1998 and 2003 studies. Curr Med Res Opin. 2008;24:507-14.

18. Mafauzy M, Hussein Z, Chan SP. The status of diabetes control in Malaysia: results of DiabCare 2008. Med J Malaysia. 2011;66:17581.

19. Soewondo P, Soegondo S, Suastika K, Pranoto A, Soeatmadji DW, Tjokroprawito A. The DiabCare Asia 2008 study-outcomes on control and complications of type 2 diabetic patients in Indonesia. Med J Indones. 2010;19:235-44.

20. Latif ZA, Jain A, Rahman MM. Evaluation of management, control, complications and psychosocial aspects of diabetics in Bangladesh: DiabCare Bangladesh 2008. Bangladesh Med Res Counc Bull. 2008;37:11-6.

21. Chetthakul T, Pongchaiyakul C, Tandhanand S. Improvement of diabetic care at Maharat Nakhon Ratchasima Hospital (the study of Diabcare-Asia from 1997 to 2003). J Med Assoc Thail. 2006;89: $56-62$.

22. Mafauzy M. Diabetes control and complications in private primary healthcare in Malaysia. Med J Malaysia. 2005;60:212-7.

23. Chuang LM, Soegondo S, Soewondo P, Young-Seol K, Mohamed M, Dalisay E, et al. Comparisons of the outcomes on control, type of management and complications status in early onset and late onset type 2 diabetes in Asia. Diabetes Res Clin Pract. 2006;71: $146-55$.

24. Janssen MF, Lubetkin EI, Sekhobo JP, Pickard AS. The use of the EQ-5D preference-based health status measure in adults with type 2 diabetes mellitus. Diabet Med. 2011;28:395-413.

25. International Diabetes Federation. IDF Diabetes Atlas, 5th edn. Brussels: International Diabetes Federation; 2011.

26. American Diabetes Association. Standards of medical care in diabetes-2018. Diabetes Care. 2018;41(Suppl 1):S1-2.

27. Do N, Oh J, Lee JS. Moving toward universal coverage of health insurance in Vietnam: barriers, facilitating factors, and lessons from Korea. J Korean Med Sci. 2014;29:919-25.

28. Abougalambou SS, Abougalambou AS. A study evaluating prevalence of hypertension and risk factors affecting on blood pressure control among type 2 diabetes patients attending teaching hospital in Malaysia. Diabetes Metab Syndr. 2013;7:83-6.

29. Chew BH, Ismail M, Lee PY, Taher SW, Haniff J, Mustapha FI. Determinants of uncontrolled dyslipidaemia among adult type 2 diabetes in Malaysia: the Malaysian Diabetes Registry 2009. Diabetes Res Clin Pract. 2012;96:339-47.

30. Stamler J, Vaccaro O, Neaton JD, Wentworth D. Diabetes, other risk factors, and 12-yr cardiovascular mortality for men screened in the Multiple Risk Factor Intervention Trial. Diabetes Care. 1993;16: 434-44.

31. Wan Nazaimoon WM, Letchuman R, Noraini N, Ropilah AR, Zainal M, Ismail IS. Systolic hypertension and duration of diabetes mellitus are important determinants of retinopathy and 
microalbuminuria in young diabetics. Diabetes Res Clin Pract. 1999;46:213-31.

32. Duggirala MK, Cuddihy RM, Cuddihy MT, Naessens JM, Cha SS, Mandrekar JN, et al. Predictors of blood pressure control in patients with diabetes and hypertension seen in primary care clinics. Am J Hypertens. 2005; 18:833-8.

33. Cheung BMY, Li C. Diabetes and hypertension: is there a common metabolic pathway? Curr Atheroscler Rep. 2012;14:160-6.

34. Khan HA, Sobki SH, Khan SA. Association between glycaemic control and serum lipids profile in type 2 diabetic patients: HbAlc predicts dyslipidaemia. Clin Exp Med. 2007;7:24-9.

35. Karim MN, Ahmed KR, Bukht MS, Akter J, Chowdhury HA, Hossain S, et al. Pattern and predictors of dyslipidemia in patients with type 2 diabetes mellitus. Diabetes Metab Syndr. 2013;7:95-100.

36. Gatti A, Maranghi M, Bacci S, Carallo C, Gnasso A, Mandosi E, et al. Poor glycemic control is an independent risk factor for low HDL cholesterol in patients with type 2 diabetes. Diabetes Care. 2009;32:1550-2.

37. Nathan DM, Bayless M, Cleary P, Genuth S, Gubitosi-Klug R, Lachin JM, et al. Diabetes control and complications trial/ epidemiology of diabetes interventions and complications study at 30 years: advances and contributions. Diabetes. 2013;62:3976-86.

38. Brod M, Galstyan G, Unnikrishnan AG, Harman-Boehm I, Prusty V, Lavalle F, et al. Self-treated hypoglycemia in type 2 diabetes mellitus: results from the second wave of an international crosssectional survey. Diabetes Ther. 2016;7:279-93.

39. Zoungas S, Patel A, Chalmers J, de Galan BE, Li Q, Billot L, et al. Severe hypoglycemia and risks of vascular events and death. N Engl J Med. 2010;363:1410-8.

40. World Medical Association (2008) Declaration of Helsinki. Ethical principles for medical research involving human subjects. Seoul: 59th WMA General Assembly

41. ISPE (International Society for Pharmacoepidemiology) (2007) Guidelines for good pharmacoepidemiology practices (GPP)

Publisher's note Springer Nature remains neutral with regard to jurisdictional claims in published maps and institutional affiliations. 